\title{
Penyuluhan Hukum : Pendirian Dan Pemberdayaan BUM Desa Mendak Kecamatan Dagangan Kabupaten Madiun
}

\author{
Sigit Sapto Nugroho ${ }^{1}$, Mudji Raharjo ${ }^{2}$, Hirman $^{3}$

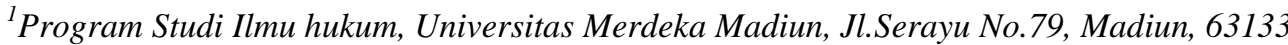 \\ E-mail: sigitsapto@unmer-madiun.ac.id \\ ${ }^{2}$ Program Studi Ilmu hukum, Universitas Merdeka Madiun, Jl.Serayu No.79, Madiun, 63133 \\ E-mail: mudjirahardjo@unmer-madiun.ac.id \\ ${ }^{3}$ Program Studi Ilmu hukum, Universitas Merdeka Madiun, Jl.Serayu No.79, Madiun, 63133 \\ E-mail: hirman@unmer-madiun.ac.id
}

\begin{abstract}
The purpose of this community service is to provide counseling and dissemination of the establishment of Village-Owned Enterprises (BUM Desa) with all formal legal aspects and the development of BUM Desa empowerment. Including Mendak Village, Dagangan Subdistrict, Madiun Regency, which has the potential of superior products in the form of fruit plants and natural tourism potential such as Watu Rumpuk tourist destinations. The implementation of community service is carried out by using methods of counseling or legal communication both directly and indirectly.Referring to the laws and regulations the establishment of BUM Desa as a village economic institution must have a strong legal basis. Where the BUM Desa privilege is located in 1) the formation of sufficient Perdes, 2) the highest authority in the hands of the Musdes, 3) ownership of at least 60\% of the village government. These three things are to maintain the sovereignty of the establishment and management of BUM Desa in the hands of the villagers. There are three factors that influence the success of BUM Desa. First, natural resources owned. The second factor is funding capital for financing. Third, the factor of Human Resources (HR).
\end{abstract}

Keywords—: Formal Legal; Establishment; BUM Desa Empowerment.

\section{PENDAHULUAN}

Badan Usaha Milik Desa (BUM Desa) ramai dibicarakan dalam kurun waktu beberapa terakhir ini, yaitu sejak diundangkannya Undang-Undang No. 6 Tahun 2014 tentang Desa (UU Desa). UU Desa berlandaskan pada ketentuan pasalpasal yang tercantum dalam UUD 1945 yang terkait dengan pemerintahan daerah, namun yang paling khusus terkait dengan keberadaan desa (meskipun tidak secara eksplisit tersebut dalam isi pasal) adalah pada Pasal 18 B ayat (2) UUD 1954 yaitu: Negara mengakui dan menghormati kesatuan-kesatuan masyarakat hukum adat beserta hak-hak tradisionalnya sepanjang masih hidup dan sesuai dengan perkembangan masyarakat dan prinsip Negara Kesatuan Republik Indonesia, yang diatur dalam undang-undang. ${ }^{1}$

Badan Usaha Milik Desa, bisa disingkat BUM Desa adalah amanat UU No. 6 Tahun 2014 tentang Desa. Jika di tingkat pusat dikenal Badan Usaha Milik Negara (BUMN), di level provinsi atau kabupaten/kota dikenal Badan Usaha Milik Daerah (BUMD), maka di desa dikenal BUM Desa.

BUM Desa, menurut Pasal 1 angka 6 UU Desa, adalah badan usaha yang seluruh atau sebagian besar modalnya dimiliki oleh desa melalui penyertaan secara langsung yang berasal dari kekayaan desa yang dipisahkan guna mengelola aset, jasa pelayanan, dan usaha lainnya untuk sebesar-besarnya kesejahteraan masyarakat desa.

Berkaitan dengan pemerintahan daerah, maka pemahaman tentang desa tidak bisa terlepas dari peraturan yang terkait dengan pemerintahan daerah, yaitu yang diundangkan dalam Undang-Undang No. 32 Tahun 2004. Dalam undang-undang ini, desa disebut secara definitif dan keberadaan BUM Desa sudah diakui, yaitu disebut dalam Pasal 213: (1) Desa dapat mendirikan badan usaha milik desa sesuai dengan kebutuhan dan potensi desa; (2) Badan usaha milik desa sebagaimana dimaksud ayat (1) berpedoman pada peraturan perundang-undangan; (3) Badan usaha milik desa sebagaimana dimaksud ayat (1) dapat melakukan pinjaman sesuai peraturan perundang-undangan.

Dalam penjelasan Undang-Undang Pemerintahan Daerah Pasal 213 tersebut, khususnya ayat (2) disebutkan bahwa Badan Usaha Milik Desa adalah badan hukum sebagaimana diatur dalam peraturan perundang-undangan.

Selanjutnya tentang desa, terdapat sedikit perbedaan definisi dalam UU Pemerintahan Daerah dan dalam UU Desa. Dalam UU Pemerintahan Daerah disebutkan bahwa desa adalah kesatuan masyarakat hukum yang memiliki batas-batas wilayah yang berwenang untuk mengatur dan mengurus kepentingan masyarakat setempat, berdasarkan asal-usul dan adat istiadat setempat yang diakui dan dihormati dalam sistem Pemerintahan Negara Kesatuan Republik Indonesia.

\footnotetext{
${ }^{1}$ Departemen Pendidikan Nasional Pusat Kajian Dinamika Sistem Pembangunan (PKDSP). 2007, Buku Panduan Pendirian dan Pengelolaan Badan Usaha Milik Desa (BUMDes), Surabaya: Fakultas Ekonomi Universitas Brawijaya., hal 3
} 
Website : http://dayamas.unmermadiun.ac.id/index.php/dayamas

Dalam UU Desa disebutkan mengenai batasan desa yang lebih luas yaitu meliputi desa dan desa adat, yaitu desa adalah desa dan desa adat atau yang disebut dengan nama lain, selanjutnya disebut Desa, adalah kesatuan masyarakat hukum yang memiliki batas wilayah yang berwenang untuk mengatur dan mengurus urusan pemerintahan, kepentingan masyarakat setempat berdasarkan prakarsa masyarakat, hak asal usul, dan/atau hak tradisional yang diakui dan dihormati dalam sistem pemerintahan Negara Kesatuan Republik Indonesia. ${ }^{2}$

Dengan demikian eksistensi BUM Desa sebagai lembaga ekonomi sudah diakui sejak tahun 2004, namun peraturan perundangan yang membahas lebih rinci tentang BUM Desa baru tersedia pada tahun 2014.

\section{METODE PENYULUHAN HUKUM}

Metode yang digunakan dalam pelaksanaan pengabdian kepada masyarakat ini menggunakan metode penyuluhan hukum, Metode Penyuluhan adalah cara yang sistematis untuk menyampaikan pesan agar dapat terjadi perubahan sehingga sasaran mengetahui dan mau serta mampu dalam menerapkan substansi materi yang disampaikan. Setiap orang belajar lebih banyak melalui cara yang berbeda-beda sesuai dengan kemampuan dalam menangkap pesan yang diterimanya, ada yang cukup dengan mendengar saja, atau melihat dan juga ada yang harus mempraktikkan dan kemudian mendistribusikannya. Namun dilain pihak, penggunaan kombinasi dari berbagai metode penyuluhan akan banyak membantu mempercepat proses perubahan.

Berdasarkan teknik komunikasi, metode penyuluhan dibagi menjadi 2 golongan, yaitu:

1. Metode penyuluhan langsung. Artinya para petugas penyuluhan, langsung bertatap muka dengan sasaran. Misalnya anjangsana, kontak personal, demonstrasi, dll.

2. Metode penyuluhan tidak langsung. Dalam hal ini pesan yang disampaikan tidak secara langsung

Penyuluhan hukum adalah salah satu kegiatan penyebarluasan informasi dan pemahaman terhadap norma hukum dan peraturan perundang-undangan yang berlaku guna mewujudkan dan mengembangkan kesadaran hukum masyarakat sehingga tercipta budaya hukum dalam bentuk tertib dan taat atau patuh terhadap norma hukum dan peraturan perundang-undangan yang berlaku demi tegaknya supremasi hukum. ${ }^{3}$

\section{III.PEMBAHASAN}

\section{A. Profil Desa Mendak Kecamatan Dagangan Kabupaten Madiun}

Desa Mendak terletak di Kecamatan Dagangan, Kabupaten Madiun, Propinsi Jawa Timur,Indonesia. Terletak diantara koordinat Bujur : 111.6284716 dan Koordinat Lintang : -7. 7741129 . Berada di ketinggian $400-700$ meter di atas permukaan laut.

Desa Mendak salah satu dari 17 desa yang ada di Kecamatan Dagangan yang terletak kurang lebih $15 \mathrm{~km}$ ke arah Timur dari Kecamatan Dagangan, Desa Mendak mempunyai wilayah seluas : 402 ha dengan batas - batas wilayah sbb:

- Sebelah Utara : Desa Segulung.

- Sebelah Timur $\quad$ : Kawasan hutan lindung Perhutani.

- Sebelah Selatan : : Desa Ngebel Kabupaten Ponorogo.

- Sebelah Barat : : Desa Segulung dan Desa Tileng.

Gambar 1. Peta Wilayah Desa Mendak PETA DESA MENDAK

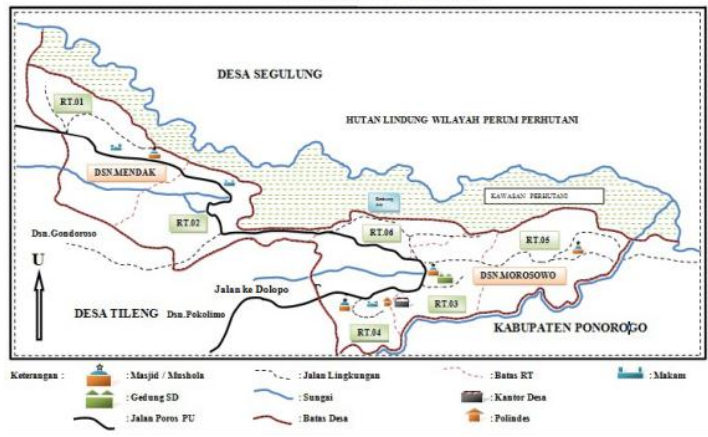

Secara umum keadaan topografi Desa Mendak adalah merupakan daerah dataran tinggi tetapi lebih banyak kawasan berbukit dan lereng gunung. Secara administrasi pemerintahan Desa Mendak terdiri dari 2 Dusun yaitu Dusen Mendak terdiri 1 (satu) Rukun Warga (RW), 2 (dua) Rukun Tetangga (RT) dan Dusun Morosowo terdiri satu RW dan 4 RT.

\footnotetext{
${ }^{2}$ Kartohadikoesoemo, Soetardjo, 2004, Desa, Jakarta: PN Balai Pustaka., hal 56

${ }^{3}$ Pasal 1 Angka 1 Peraturan Menteri Hukum dan HAM RI Nomor : M-01.PR.08.10 Tahun 2007 Tentang Perubahan atas Peraturan Menteri Hukum dan Hak Asasi Manusia RI Nomor : M-01.PR.08.10 Tahun 2006 Tentang Pola Penyuluhan Hukum Tentang Pola Penyuluhan Hukum
} 
Website : http://dayamas.unmermadiun.ac.id/index.php/dayamas

Secara sosial ekonomi mayoritas mata pencarian penduduk Desa Mendak bergerak dibidang pertanian. Hal ini menunjukkan bahwa sektor pertanian memegang peranan penting dalam bidang ekonomi masyarakat desa terutama sector perkebunan buahbuahan seperti Durian, Manggis, Mangga, Alpukat dll.

Tingkat angka kemiskinan Desa Mendak yang masih tinggi menjadikan Desa Mendak harus bisa mencari peluang lain yang bisa menunjang peningkatan taraf ekonomi bagi masyarakat antara lain dengan mengembangkan potensi pariwisata dan hasil kebun buah-buahan melalui pendirian Badan Usaha Milik Desa (BUM Desa).

Sejak 2016, potensi Wisata saat ini mulai dikembangkan di Desa Mendak, khususnya wisata yang dinamakan Watu Rumpuk. Awalnya, lokawisata Watu Rumpuk merupakan bekas tambang batu. Pemerintah Desa Mendak mampu menyulapnya menjadi destinasi wisata yang sangat menarik.Ide pengembangan lokawisata Waturumpuk muncul saat warga Desa Mendak gagal panen. Menurut Nur Cholifah, Kepala Desa komoditi cengkeh selama ini menjadi penopang perekonomian warga. Saat gagal panen, perekonomian warga turun drastis.Setelah peristiwa tragis di atas, masyarakat desa menggelar musyawarah yang mendirikan Badan Usaha Milik Desa (BUMDes) untuk mengembangan usaha alternatif. Lahirlah, unit usaha untuk mengelola desa wisata. ${ }^{4}$

\section{B. Materi Pengabdian Kepada Masyarakat}

Pelaksanaan pengabdian kepada masyarakat di Desa Mendak kecamatan Dagangan Kabupaten Madiun mengambil tema tentang penyuluhan hukum pendirian dan pemberdayaan BUM Desa, Adapun materi pengabdian dapat dijelaskan sebagai berikut:

\section{Prinsip-Prinsip Pendirian BUM Desa}

Pembentukan BUM Desa disesuaikan dengan kebutuhan dan kondisi riil suatu desa, maka BUM Desa memiliki karakter khusus. Pendiriannya tergantung pemerintahan dan warga desa, yang diatur dalam Peraturan Desa (Perdes). Berdasarkan Pasal 88 UU Desa, BUM Desa dibentuk melalui musyawarah desa.

Berdasarkan uraian di atas Lantas apa saja prinsip pendirian BUM Desaa? UU Desa memuat satu dua pasal tentang pendirian desa. Pengaturan lebih lanjut dimuat dalam Peraturan Menteri Desa PDT dan Transmigrasi No. 4 Tahun 2015, yang diundangkan 18 Februari 2015.

Ada beberapa prinsip yang penting dipahami dalam pendirian BUM Des antara lain : ${ }^{5}$

Pertama, payung hukum pendirian. BUM Desa dibentuk melalui Perdes. Sesuai konsep UU No. 6 Tahun 2014, maka Perdes itu juga harus dicatatkan di Lembaran Desa. Ada atau tidak Peraturan Daerah tentang Pembentukan BUM Desa, masyarakat desa dapat membentuk BUM Desa asalkan diatur dalam Perdes tentang Pendirian BUM Desa.

Kedua, Undang-Undang hanya menyaratkan BUM Desa didirikan melalui Musyawarah Desa, bukan melalui akta notaries apalagi pendaftaran ke Kementerian Hukum dan HAM.

Ketiga, jangan asal mendirikan BUM Desa. Pendirian badan usaha ini seharusnya disesuaikan dengan kondisi ekonomi, sosial budaya masyarakat. Keempat, bahas secara jelas organisasi pengelola BUM Desa dan orang-orang yang punya kapasitas untuk mengelola organisasi BUM Desa. Organisasi BUM Desa terdiri dari penasihat, pelaksana operasional, dan pengawas.

Yang tak kalah penting, kelima, adalah siapkan modal usaha. Undang-Undang hanya menentukan seluruh atau sebagian besar modal usaha BUM Desa adalah milik desa. Kalau ia berasal dari kekayaan desa, maka kekayaan desa itu harus dipisahkan. Itu juga berarti ada peluang bagi pihak ketiga untuk menanamkan modal di BUM Desa. Prinsip keenam, mempersiapkan Anggaran Dasar dan Anggaran Rumah Tangga BUM Desa. Jangan sampai BUM Desa berdiri dan menjalankan operasional tanpa pedoman usaha yang jelas.

\section{BUM Desa sebagai Badan Hukum}

BUM Desa merupakan salah satu lembaga ekonomi yang diharapkan dapat menjadi salah satu yang berkontribusi pada sumber pendapatan desa. Namun keberadaan BUM Desa perlu mendapatkan justifikasi hukum yang pasti. Ketentuan pada UU Pemerintahan Daerah jelas menyebutkan bahwa BUM Desa merupakan badan hukum. Satu pertanyaan yang muncul adalah : bagaimanakah mengidentifikasi BUM Desa sebagai badan hukum? Untuk dapat menjawab hal tersebut, maka harus merujuk secara spesifik pada Undang-Undang Desa dan peraturan pelaksanaannya yaitu Peraturan Pemerintah No. 43 Tahun 2014 (PP Desa). Dalam UU Desa dan juga PP Desa disebutkan bahwa Badan Usaha Milik Desa, yang selanjutnya disebut BUM Desa, adalah badan usaha yang seluruh atau sebagian besar modalnya dimiliki oleh Desa melalui penyertaan secara langsung yang berasal dari kekayaan Desa yang dipisahkan guna mengelola aset, jasa pelayanan, dan usaha lainnya untuk sebesarbesarnya kesejahteraan masyarakat Desa.

Selanjutnya dalam Bab X Pasal 87 UU Desa diatur bahwa:(1) desa dapat mendirikan Badan Usaha Milik Desa yang disebut BUM Desa; (2) BUM Desa dikelola dengan semangat kekeluargaan dan kegotongroyongan; (3) BUM Desa dapat menjalankan usaha di bidang ekonomi dan/atau pelayanan umum sesuai dengan ketentuan peraturan perundang-undangan.

Pada pasal 88 UU Desa jo. Pasal 132 PP Desa disebutkan bahwa BUM Desa didirikan berdasarkan musyawarah desa yang kemudian hasil musyawarah tersebut ditetapkan dengan Peraturan Desa. Selanjutnya dalam Pasal 135 PP Desa disebutkan

\footnotetext{
${ }^{4}$ Wawancara dengan Nur Cholifah, Kepala Desa Mendak Kecamatan Dagangan Kabupaten Madiun

${ }^{5}$ Zulkarnain Ridlwan, Payung Hukum Pendirian BUMDes, Fiat Justitia Jurnal Ilmu Hukum Volume 7 No. 3, Sept - Des. 2013
} 
Website : http://dayamas.unmermadiun.ac.id/index.php/dayamas

bahwa modal awal BUM Desa bersumber dari APB Desa yang merupakan kekayaan Desa yang dipisahkan dan tidak terbagi atas saham. Modal BUM Desa terdiri dari : 1) Penyertaan Modal Desa, yang berasal dari APB Desa dan lainnya; 2) Penyertaan Modal Masyarakat Desa.

Status BUM Desa sebagai badan hukum dikukuhkan melalui undang-undang, namun sebagai badan hukum, ia harus memiliki organisasi yang teratur. Organisasi yang teratur ini dapat dilihat dalam Pasal 132 PP Desa yang menyebutkan bahwa Pengelola BUM Desa setidaknya harus terdiri dari : 1) Penasehat; dan 2) Pelaksana Operasional. Penasehat secara ex-officio dijabat oleh Kepala Desa, sedangkan Pelaksana Operasional adalah perseorangan yang diangkat dan diberhentikan oleh Kepala Desa.

Tidak seperti badan hukum layaknya Perseroan Terbatas, Yayasan ataupun Koperasi, dimana kesemuanya mendapatkan statusnya sebagai badan hukum saat mendapatkan pengesahan dari menteri terkait. Dalam UU Desa dan PP Desa tidak disebutkan secara eksplisit saat mana BUM Desa sah menjadi sebuah badan hukum. Namun dari Pasal 88 UU Desa jo. Pasal 132 PP Desa yang menyebutkan bahwa "Pendirian BUM Desa dilakukan melalui musyawarah Desa dan ditetapkan dengan peraturan Desa" maka dapat disimpulkan bahwa saat telah disahkannya kesepakatan dalam musyawarah Desa dan kesepakatan tersebut ditetapkan dalam suatu Peraturan Desa, maka pada saat itulah telah lahir BUM Desa sebagai badan hukum. ${ }^{6}$

Dari beberapa aturan tersebut di atas terlihat bahwa BUM Desa memang dibentuk dengan konsep sebagai badan hukum. Untuk dapat disebut sebagai badan hukum, maka harus memiliki karakteristik antara lain yaitu : 1) Adanya harta kekayaan yang terpisah; 2) Mempunyai tujuan tertentu; 3) Mempunyai kepentingan sendiri; 4) Adanya organisasi yang teratur. Keempat ciri tersebut tercermin dalam ketentuan yang mengatur tentang BUM Desa tersebut. Kekayaan BUM Desa merupakan kekayaan Desa yang dipisahkan. BUM Desa juga memiliki tujuan dan kepentingan yang ditetapkan oleh undang-undang yaitu untuk mengembangkan perekonomian desa dan meningkatkan pendapatan desa. BUM Desa juga memiliki organisasi yang teratur yang dapat dilihat dari adanya penasehat dan pelakasana operasional.

Keistimewaan BUM Desa terletak pada 1) pembentukan cukup Perdes, 2) kekuasaan tertinggi di tangan Musdes, 3) kepemilikan minimal $60 \%$ pemerintah desa. Ketiga hal tersebut untuk menjaga kedaulatan pendirian dan pengelolaan BUM Desa di tangan warga desa.

Berdasarkan filosofi tersebut, BUM Desa tidak boleh hadir, bersaing dengan warga, apalagi mengambil dan mematikan aktivitas-aktivitas ekonomi yang sudah dijalankan oleh warga. Sebaliknya, BUM Desa harus hadir dengan memberikan nilai tambah bagi masyarakat desa, seperti contoh yang dilakukan masyarakat Desa Mendak dengan mendirikan BUM Desa wisata, khususnya mengelola destinasi wisata Watu Rumpuk.

Setidaknya ada tiga faktor yang mempengaruhi keberhasilan sebuah desa membentuk dan mengelola BUMDes. Pertama sumber daya alam yang dimiliki desa tersebut. Apa saja sumber daya yang secara alami tersedia di desa itu dan apalah selama ini sudah diolah sedemikian rupa. Pengelolaan sumber alam yang baik akan menghasilkan manfaat sosial baik profit maupun benefit. Seperti yang dilakukan Desa Mendak dengan destinasi wisata alam Watu Rumpuk.

Kedua faktor modal pendanaan untuk pembiayaan berbagai operasional hingga tercapai produktivitas yang tinggi dalam memenuhi kebutuhan pasar. Penyertaan modal adalah salahsatu kekuatan BUMDes mengembang. Tetapi sebelum rupiah dikucurkan, Kepala Desa harus yakin bahwa BUMDes telah menyusun business plan yang baik. Business Plan sangat penting dalam membangun sebuah usaha karena akan menjadi pedoman bagaimana bisnis itu akan dijalankan.

Business Plan juga kan menjadi memberikan gambaran yang jelas mengenai apa bisnis yang akan dijalankan, bagaimana menjalankan termasuk kebutuhan permodalan dan pasar yang dituju untuk menjual produk.

Ketiga, faktor yang paling utama keberhasilan BUMDes sesungguhnya bukan sumber daya alam tau modal uang penyertaan melainkan Sumber Daya Manusia (SDM). Bagaimanapun semua potensi yang ada bakal terbukti bisa menjadi komoditas yang produktif atau tidak semuanya tergantung pada bagaimana SDM mengelolanya.

\section{IV.DAFTAR PUSTAKA}

Departemen Pendidikan Nasional Pusat Kajian Dinamika Sistem Pembangunan (PKDSP). 2007, Buku Panduan Pendirian dan Pengelolaan Badan Usaha Milik Desa (BUM Desa), Surabaya: Fakultas Ekonomi Universitas Brawijaya.

Kartohadikoesoemo, Soetardjo, 2004, Desa, Jakarta: PN Balai Pustaka.

Muh Sayuti, Pelembagaan BUM Desa sebagai Penggerak Potensi Ekonomi Desa dalam rangka Pengentasan Kemiskinan, Jurnal Academia Fisip Untad, Vol.3 Oktober 2011

Zulkarnain Ridlwan, Payung Hukum Pendirian BUM Desa, Fiat Justitia Jurnal Ilmu Hukum Volume 7 No. 3, Sept - Des. 2013

Peraturan Perundangan :

Undang-Undang Dasar Negara Republik Indonesia Tahun 1945

Undang-Undang Nomor 6 Tahun 2014 tentang Desa

Peraturan Pemerintah Nomor 43 Tahun 2014 tentang Peraturan Pelaksana Undang-Undang Nomor 6 Tahun 2014 tentang Desa

Peraturan Menteri Desa PDT dan Transmigrasi Nomor 4 Tahun 2015 tentang Badan Usaha Milik Desa

Peraturan Menteri Hukum dan HAM RI Nomor : M-01.PR.08.10 Tahun 2007 Tentang Perubahan atas Peraturan Menteri Hukum dan Hak Asasi Manusia RI Nomor : M-01.PR.08.10 Tahun 2006 Tentang Pola Penyuluhan Hukum Tentang Pola Penyuluhan Hukum.

\footnotetext{
${ }^{6}$ Muh Sayuti, Pelembagaan BUMDes sebagai Penggerak Potensi Ekonomi Desa dalam rangka Pengentasan Kemiskinan, Jurnal Academia Fisip Untad, Vol.3
} Oktober 2011 